\title{
Inn i klasserommet
}

\section{Af Harriet BJerrum Nielsen}
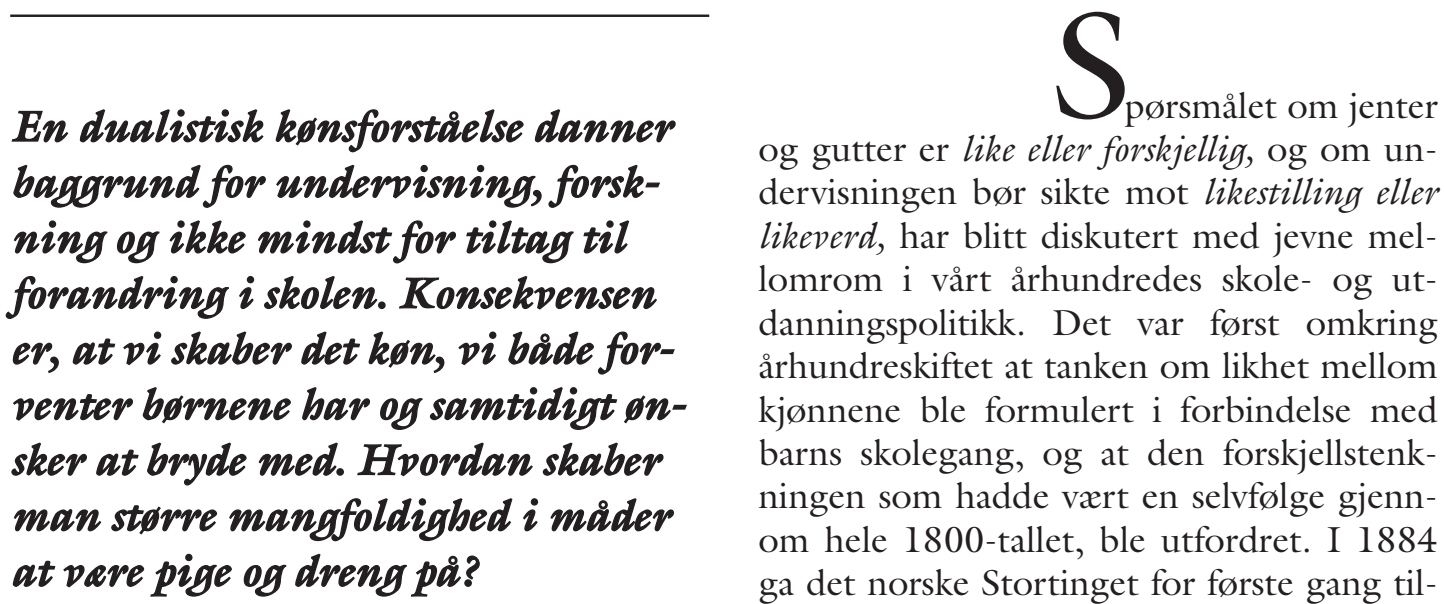
og gutter er like eller forskjellig, og om undervisningen bør sikte mot likestilling eller likeverd, har blitt diskutert med jevne mellomrom $\mathrm{i}$ vårt århundredes skole- og utdanningspolitikk. Det var først omkring århundreskiftet at tanken om likhet mellom kjønnene ble formulert i forbindelse med barns skolegang, og at den forskjellstenkningen som hadde vært en selvfølge gjennom hele 1800-tallet, ble utfordret. I 1884 ga det norske Stortinget for første gang tillatelse til at jenter og gutter kunne gå sammen i middelskole og det vakte debatt. Stred ikke dette mot kjønnenes forskjellige natur og bestemmelse? Eller var det tvert imot en forutsetning for likestilling og et mer naturlig forhold mellom kjønnene? Eller ville resultatet bare bli at jentene fikk undervisning på gutteskolens premisser (Kruse 1989)? Resultatet i Norge utover på 1900-tallet ble fellesskoler (mest fordi det ble for dyrt å ha kjønnsatskilte skoler), men ikke nødvendigvis fellesundervisning. At 
skilte jente- og gutteklasser var alminnelige i byene helt fram til 1950-tallet og jentene hadde færre timer i fag som norsk og matte fordi det skulle være plass til husstell på timeplanen (Brock-Utne \& Haukaa 1980). I Danmark førte spørsmålet om fellesskole til en mer voldsom debatt, men her ble resultatet til gjengjeld fellesundervisning fra starten av, dog med særordninger for jentene som liknet på de norske: obligatorisk håndarbeid, mulighet for fritak fra praktisk regning og matematikk, og mulighet for et hvileår i puberteten. De siste to ordninger besto formelt fram til folkeskoleloven av 1958, men mistet sin praktiske betydning lenge før det. Obligatorisk håndarbeid bare for jenter var det helt fram til folkeskoleloven av 1975.

De siste rester av 1800-tallets forskjellstenkning når det gjaldt barn, forsvant $\mathrm{i}$ løpet av 1950-årene. Både klasse- og kjønns rolleoppdragelse ble nå ansett som en foreldet tanke og et forlengst tilbakelagt stadium. I noen årtier fram var jenter og gutter bare elever. Likhetstenkning og velferdspolitikk sto i sentrum i etterkrigsårene og i pedagogikken kom utviklingspsykologi og intelligensprøver i fokus. Det var barnas individuelle evner og anlegg som skulle bestemme hvor langt de kom i utdanningssystemet - verken bosted, sosial klasse eller barnas kjønn skulle bety noe i et opplyst, moderne samfunn. Det som først kom til syne igjen hos etterkrigstidens kjønns- og klassenøytrale barn, var klassetilhørigheten. Det kunne ikke underslås at skolen reproduserte de sosiale klasseforskjellene, og at det sosialdemokratiske håp om å fjerne sosial ulikhet gjennom utdanning ikke var lyktes særlig langt. Omkring 1970 fikk elevene altså klasse, men kjønn var fortsatt usynlig.

Da pedagogiske kvinneforskere på slutten av 1970-tallet begynte å spørre til hvordan jentene egentlig hadde det på skolen, var det mange som syntes det var unødvendig. At kjønn skulle spille noen rolle, var en gammeldags misforståelse som vi heldigvis var ferdige med. Og det var jo ikke noe å si på jentene! De var bra elever som fikk de beste karakterer. Skulle de nå også gjøres til et problem?!

\section{KJØNNSFORSKJELLER I KLASSEROMMET}

Problemet ble først kartlagt gjennom statistiske undersøkelser av skoleprestasjoner, utdanningsvalg og yrkeskarriere. Jentene så ut til å klare seg bedre i skolen enn gutter, men var ikke desto mindre underrepresentert i videregående og høgre utdanning, og overrepresentert i dårlig betalte jobber med lav status og liten innflytelse (Ørum 1973, Brock-Utne \& Haukaa 1980, Arnmann \& Jönsson 1986, Yates 1998). I Danmark viste en stor statistisk undersøkelse at jentene klarte seg bra frem til 7.klasse, for deretter å tape terreng både når det gjaldt karakterer, ambisjoner og videre utdanning. Undersøkelsen konkluderte med at 'kønsrollen slår i gennem på et eller andet tidspunkt i elevenes oplevelse og adfærd' (Ørum 1973, 35). Spørsmålene begynte å melde seg: Var virkelig jentene kjønnsnøytrale elever fram til puberteten - og deretter plutselig kvinner med et tradisjonelt kvinnelig livsperspektiv? Hvordan kunne det henge sammen? Statististiske undersøkelser kunne ikke gi svar på slike spørsmål - tiden var kommet for å se nærmere på hva som skjedde inne i klasserommet. Klasseromsstudier var blitt vanlige i løpet av 1970-tallet, i bestrebelsene på å forstå hvordan skolen forskjellsbehandlet middelklassebarn og arbeiderbarn. Men ingen hadde spurt etter kjønn - i 1970-årenes klasseromsstudier er 'middelklassebarn' og 'arbeiderbarn' stort sett gutter. Det ble i hvert fall ikke bemerket hvem av arbeiderbarna som ble gjort tause, og hvem som skapte disiplinproblemer i klassen (Bjerrum Nielsen 1998).

Den klasseromsforskningen som fulgte utover på 1970- og 80-tallet, viste at kjønn hadde forblitt et grunnleggende organiserende prinsipp i skolen under kjønnsnøytralitetens regime. Ulike typer av kjønnstypifi- 


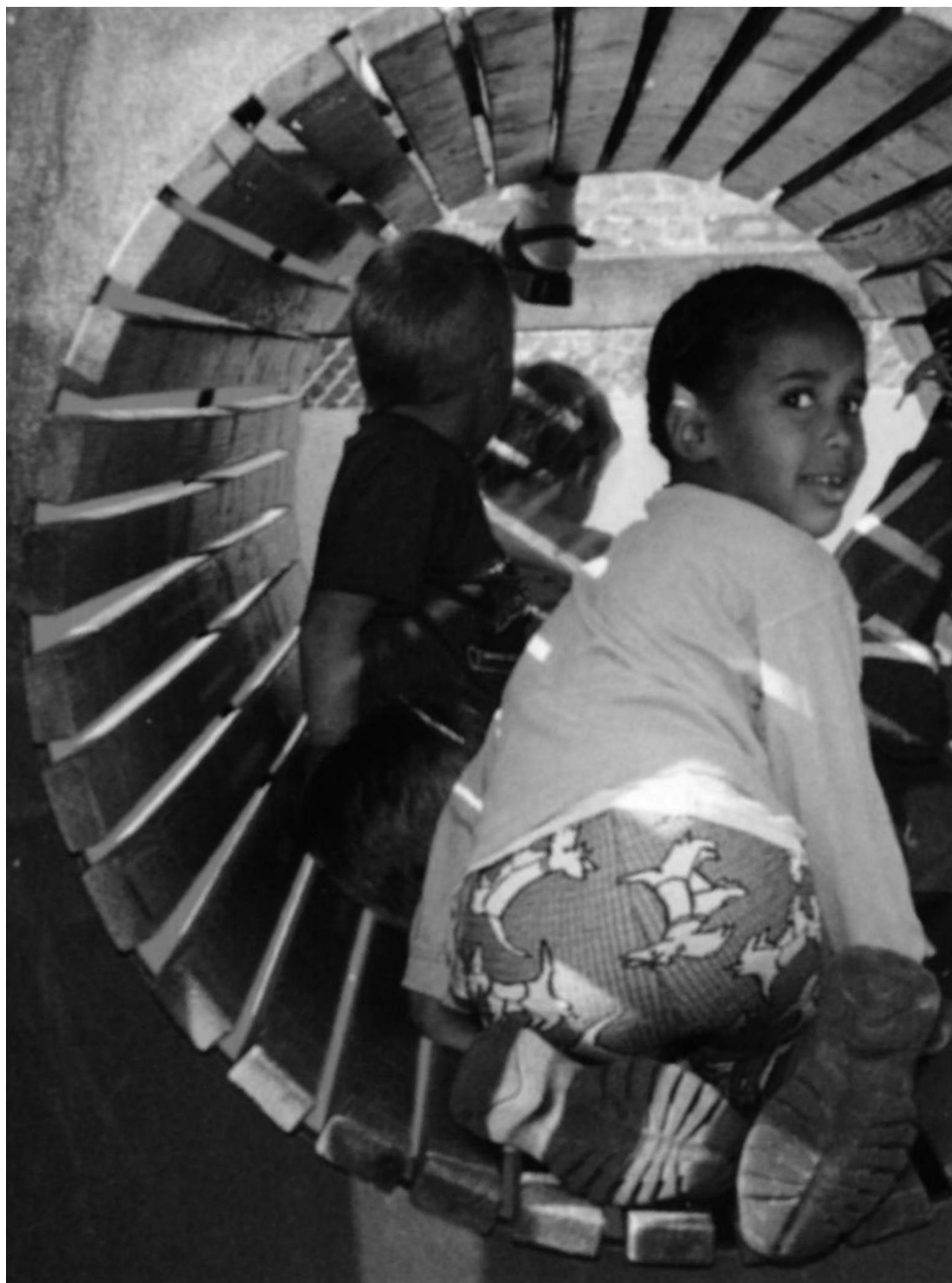




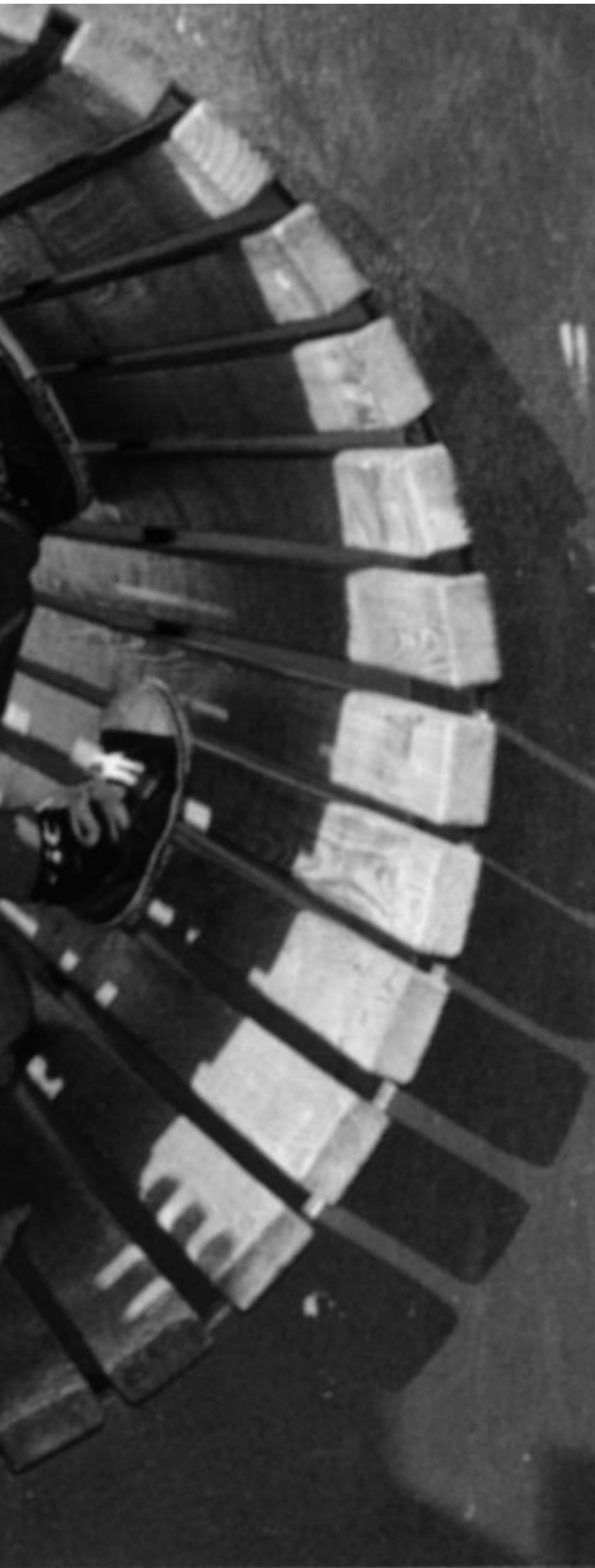

sering av barn (til skolefesten kan jentene bake og guttene kjøpe brus), i skolebøkene (far leser og mor syr), kjønnsbaserte strategier for å håndtere og kontrollere klasserommet (Ola, sett deg ned til Kari slik at hun kan holde litt orden på deg) ble dokumentert både i norske og utenlandske undersøkelser. Men det som først og fremst vakte oppsikt var at lærerne - uten å vite det - systematisk ga jentene mindre oppmerksomhet enn guttene. Den som var tidligst ute i en nordisk sammenheng, var den svenske pedagogiske forsker Inga Wernersson, som i 1977 utga doktoravhandlingen Könsdifferentiering $i$ grundskolan. I Norge kom Birgit Brock-Utnes og Runa Haukaas Kunnskap uten makt i 1980, og i Danmark samme år lanserte Marianne Kristiansen begrepet 'de stille piger' (Kristiansen 1980). Deretter fulgte i raskt tempo en rekke forskningsprosjekter, som alle bidro til å synliggjøre jentenes skjebne i klasserommet. Disse undersøkelsene viste, liksom utenlandske studier fra samme periode, at den moderne barnesentrerte skoles kjønnsnøytralitet var en illusjon. Jentene var bipersoner i klasserommet.

Klasseromsstudier, hva enten de er kvantitative eller kvalitative, krever at forskeren er tilstede i hver enkelt klasse hun studerer, og det betyr at det er begrenset hvor mange skoleklasser som kan inngå i hver undersøkelse. Det har imidlertid blitt gjort sammenligninger av en del undersøkelser og resultatene fra dem viser ganske stor konsistens. Den engelske pedagogiske forsker Alison Kelly (1988) viste i en slik sammenlignende analyse av 81 kvantitative klasseromsstudier fra USA, Canada, England, Australia og Sverige at i alle disse land, på tvers av klassetrinn, av fag og av elevenes sosiale og etniske bakgrunn, fikk jentene færre faglige instruksjoner, færre avanserte spørsmål og mindre faglig respons, færre irettesettelser og lidt mindre ros enn gutter. Lærerens kjønn betydde ikke stort, men Kelly fant likevel en svak tendens til at mannlige lærere ga mest oppmerksomhet 
til gutter. Ifølge Kellys analyse er jentene like ivrige for å svare på lærerens spørsmål som guttene, men de tar færre egne initiativer. Det samme fant vi i en dansk undersøkelse: Selvom jenter og gutter her fikk noenlunde samme antall spørsmål fra læreren, så betydde den overveldende mengden av uoppfordrede kommentarer fra guttene at de fikk mye mer lærerrespons enn jentene. Kjønnsforskjellen økte dramatisk fra 1 . til 3.klasse: Mens 1.klasseguttene tok dobbelt så mange initiativer som jentene, tok 3.klasseguttene ti ganger så mange! En annen interessant forskjell var at mens 1 . klassejentene ofte fikk negativ respons på sine initiativer, fikk 3.klassejentene nesten bare ros. For guttene var det omvendt - de fikk mindre positiv respons i 3.klasse enn i 1.klasse. Likevel fikk de - også i 3.klasse langt mer respons og langt mer positiv respons enn jentene, når man så det i absolutte tal (Bjerrum Nielsen \& Larsen 1985).

Hvilke kjønnede samtalemønstre dekker slike tall over? En typisk samhandlingssekvens i grunnskolen viste seg å gå slik for seg: Læreren stiller et spørsmål. Ei jente rekker opp hånden og får lov å svare. Det gjør hun kort og som oftest riktig. En gutt avbryter med en interessant kommentar til temaet, læreren glemmer jenta og diskuterer med gutten. Flere gutter melder seg med synspunkter. Jentene venter tause på neste spørsmål eller benytter ventetiden til å rydde i pennalet eller hviske lavt med hverandre. Jentene får ros for å svare i korrekt form, mens guttene får ros hvis innholdet $\mathrm{i}$ det de sier, er riktig eller interessant (Einarsson \& Hultman 1984, Bjerrum Nielsen 1981, Bjerrum Nielsen \& Larsen $1985)$.

Nå er det ikke alle gutter som er like heldige, når de tar ordet uoppfordret. Amerikanerne Good, Sikes \& Brophy (1973) fant, at prestasjonsnivå betydde mer for lærerens respons til gutter enn til jenter. Lavt presterende gutter fikk flere irettesettelser, mens de dyktige gutter fikk 'det beste av alt' - dvs. mest ros, mest faglig re- spons, flest avanserte spørsmål. I denne undersøkelsen fikk de lavt presterende jentene minst oppmerksomhet av alle, mens andre undersøkelser har funnet, at det er de dyktige jenter som blir mest oversett (Kelly 1988, Öhrn 1991). Fra 1970-tallets undersøkelser vet vi at prestasjonsnivå er klart relatert til elevenes sosiale bakgrunn. Dette viser, at kjønn og klasse virker sammen, og at kjønn utrykker seg klassespesifikt og vice versa.

Selv om responsens retning blir påvirket av klassebakgrunn, så er det likevel klart at guttene generelt er mye tydeligere til stede i lærernes bevissthet både i og utenfor klasserommet. Lxrere som blir bedt om å fortelle om sine elever, forteller mer differensiert og med større personlig engasjement om gutter enn om jenter. Guttene framstilles som individer, mens jentene framstilles gruppevis (Wernersson 1977). I en engelsk undersøkelse fortalte en lærer om alle de forskjellige guttene han hadde i klassen sin, og avsluttet med ordene: 'og resten er jenter' (Stanworth 1983). Denne oppfattelse av jenter som en ensartet flokk ser også ut til å gjelde selv om jentene er aktive og dominerende i klasserommet. Elisabeth Öhrn gjennomførte en klasseromsstudie i svenske 9.klasser og fant jentedominans i to av syv klasser. I de klassene omtalte lærerne jentene som ‘jentemafiaen’ (Öhrn 1991). Disse kjønnsforskjellene i samhandling og oppfattelse av elever er sjelden intenderte eller bevisste for lærerne. De opptrer også hos lærere som virkelig ønsker og prøver på å behandle jenter og gutter likt, og som tror de får det til. Lærere reagerer ofte med vantro, når de konfronteres med dokumentasjon for kjønnsskjevhetene i deres egne timer (Kelly 1988, Corson 1993). Lærerne i Öhrns undersøkelse (1991) overvurderte omfanget av jentenes deltakelse i klassesamtalene, mens det omvendte var tilfellet for guttene. De bemerket bare guttenes dominans når den var ekstremt tydelig.

Det er kanskje ikke så rart. Mønsteret er så tilvant for oss at vi knapt bemerker det. 
Kjønn blir først synlig når jenter og gutter plutselig oppfører sig annerledes enn det vi er vant med. Uregjerlige jenter irriterer mer enn uregjerlige gutter, stille gutter vekker mer bekymring enn stille jenter. Det selvfølgelige er den ureflekterte bakgrunnen for våre reflekterte handlinger: Fordi guttene oppfattes som individer som enten stiller større krav, er mer interessante elever eller mer urolige, så planlegges og gjennomføres undervisningen med dem for øye (Clarricoates 1978). Guttene melder seg ut og støynivået stiger, når undervisningen ikke interesserer dem, mens jentene synes å ha en egen evne til å utholde skolens kjedsommelighet. Jentenes tilpasning til elevrollen og deres mer samarbeidsvillige stil resulterer $\mathrm{i}$ at de făr mindre oppmerksomhet. Inga Wernersson oppsummerte sin undersøkelse fra 1970-tallets Sverige på denne måten:

"Det samlede bilde av lærernes relasjoner til elever av ulikt kjønn tyder på at jentene får noe ros for sin lydighet og konformitet, men betaler for dette ved å bli glemt, ikke å eksistere som individer i lærerens bevissthet. Hva guttene vinner og taper er mer enn for jentene avhengig av deres egne handlinger" (Wernersson 1977, 254, oversatt fra svensk).

Mens jentene beskrives som dyktige og veltilpassede elever av lærerne i barneskolen og også selv gir uttrykk for at de trives, skifter bildet når de blir litt eldre. Klasseromsforskningen tyder på at det skjer et alvorlig fall i jentenes selvtillit omkring 1314-årsalder. Deres manglende deltakelse i klassesamtalen handler nå mer om angst for å dumme sig ut og ledd ut av guttene (Jensen m.fl. 1984, Lees 1986, Bjerrum Nielsen 1988, Gilligan m.fl. 1990, Ôhrn 1991). Bildene som klasseromsstudiene gir oss fra ungdomsskolen og videregående skolen, er imidlertid mer variert enn bildet fra barneskolen. Forklaringen kan være at noen av jentene nå har lært 'skolekoden' og tør opptre individuelt, noen er blitt opposi- sjonelle, mens andre jenter har blitt stille eller oppgitte. Forskjellig evne til å takle guttene spiller nok også en rolle. Selv om jentene fortsetter med å få bedre karakterer enn guttene, så opplever likevel mange lærere at der skjer et dramatisk skifte i jentenes elevrolle i denne alder. Jentene blir mindre samarbeidsvillige og mindre interesserte i skolen og lærerne (Wernersson 1977, Davies 1984, Hjort 1984).

Skiftet i jentenes skoletilpasning skyldes kanskje en motsetning mellom skolens eksplisitte og implisitte normer for suksess. De små jentene oppfyller de eksplisitte kravene om å gjøre det læreren sier, oppføre sig pent, være flittige og samarbeide, og taper på lengre sikt fordi guttenes mer ekspansive og individualistiske oppførsel matcher de implisitte, men reelle betingelsene for suksess. Kirsten Larsen og jeg konkluderte vår analyse av jenter og gutter i klasserommet med at 'jentene er kittet i klasseundervisningen':

"Skolen har udnyttet pigernes særlige relationelle orientering i klasseundervisningens tjeneste, og når klasseundervisningen er blevet etableret som samtalerum, når der er skabt et grundlag for drengenes interessante diskussioner med læreren i et offentlig forum, bliver hun ladt tilbage som kedelig og uinteressant - men kan dog hentes frem hver gang strukturerne i klasseundervisningen trænger til at blive gjort synlige" (Bjerrum Nielsen \& Larsen 1985, 263).

\section{TRE FORKLARINGER PÅ KJØNN I KLASSEROMMET}

Det bildet som forskningen fra 1970- og 1980-tallet har gitt oss av kjønnsforskjeller i klasserommet, er ganske klart. Forklaringene på hvorfor det er slik, hvilke følger det făr for gutters og jenters utvikling, og hva læreren kan gjøre med det, har vært mer sprikende. Grovt sett kan man si at det har vært gitt tre typer av forklaringer: Den ene forklarer bildet ut fra kjønnsmakten i klasse- 
rommet, den andre ut fra kjønnsidentiteten hos elevene, og den tredje ut fra kjønnskonstruksjoner i språk og samhandling. De tre forklaringer har vært dominerende på henholdsvis 70-tallet, 80-tallet og 90-tallet, men går også i noen grad på tvers av disse tiårene. Hver forklaring făr fram visse dimensjoner og underbetoner andre, men forklaringene trenger ikke nødvendigvis utelukke hverandre. Kjønn kan på én og samme gang være uttrykk for en sosial maktstruktur, være en del av den personlige identiteten og være en gjennomgripende betydningsstruktur i kulturen. Men kjønnsmessig likhet og forskjell vektlegges forskjellig: Kjønnsmaktperspektivet ser kjønnsforskjell som noe illegitimt, kjønnsidentitetsperspektivet tar utgangspunkt i forskjellene, og kjønnskonstruksjonsperspektivet mener at kjønnsforskjeller er en språklig illusjon. I det følgende skal alle tre forklaringer omtales, men med hovedvekt på identitetsperspektivet fordi dette førte med seg en ny type av klasseromsstudier hvor samspillet mellom barna kom i sentrum, ikke bare samspillet mellom lærer og elev.

\section{Kjønnsmakt og kjønnsroller}

Denne forklaringsmåten ser klasserommets mønster av dominans og underordning mellom gutter og jenter som en direkte avspeiling av det patriarkalske samfunnets kjønnsorden. Skolebøkene og undervisningsstoffet reproduserer et tradisjonelt kjønnsrollemønster og lærerne har tradisjonelle kjønnsrolleforventninger til barna og ser guttenes utdanning som viktigere enn jentenes. Guttene favoriseres både med hensyn til taletid og undervisningstemaer, mens jentenes læres opp til passivt å godta at gutter skal få bre seg og dominere. Forskjellsbehandling, dobbeltstandarder i klasserommet og innøvelse i mindreverd hos jentene, blir forklaringen på jentenes fallende ambisjoner i ungdomsalderen (King 1978, Spender \& Sarah 1980, Delamont 1980, Brock-Utne 1982, Pettersen 1987, Gulbrandsen 1993).

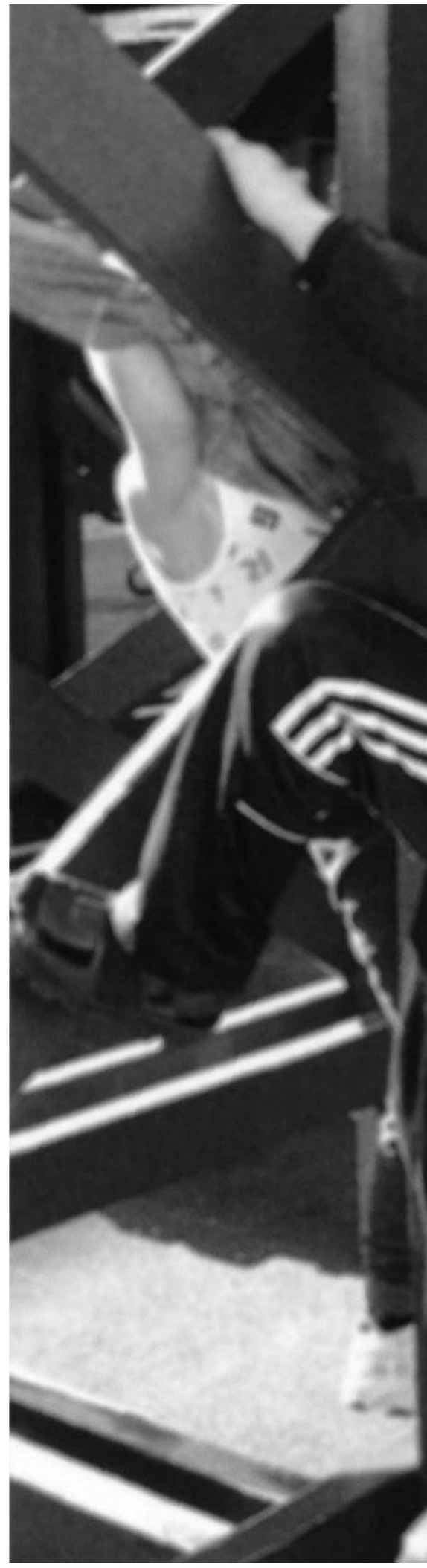




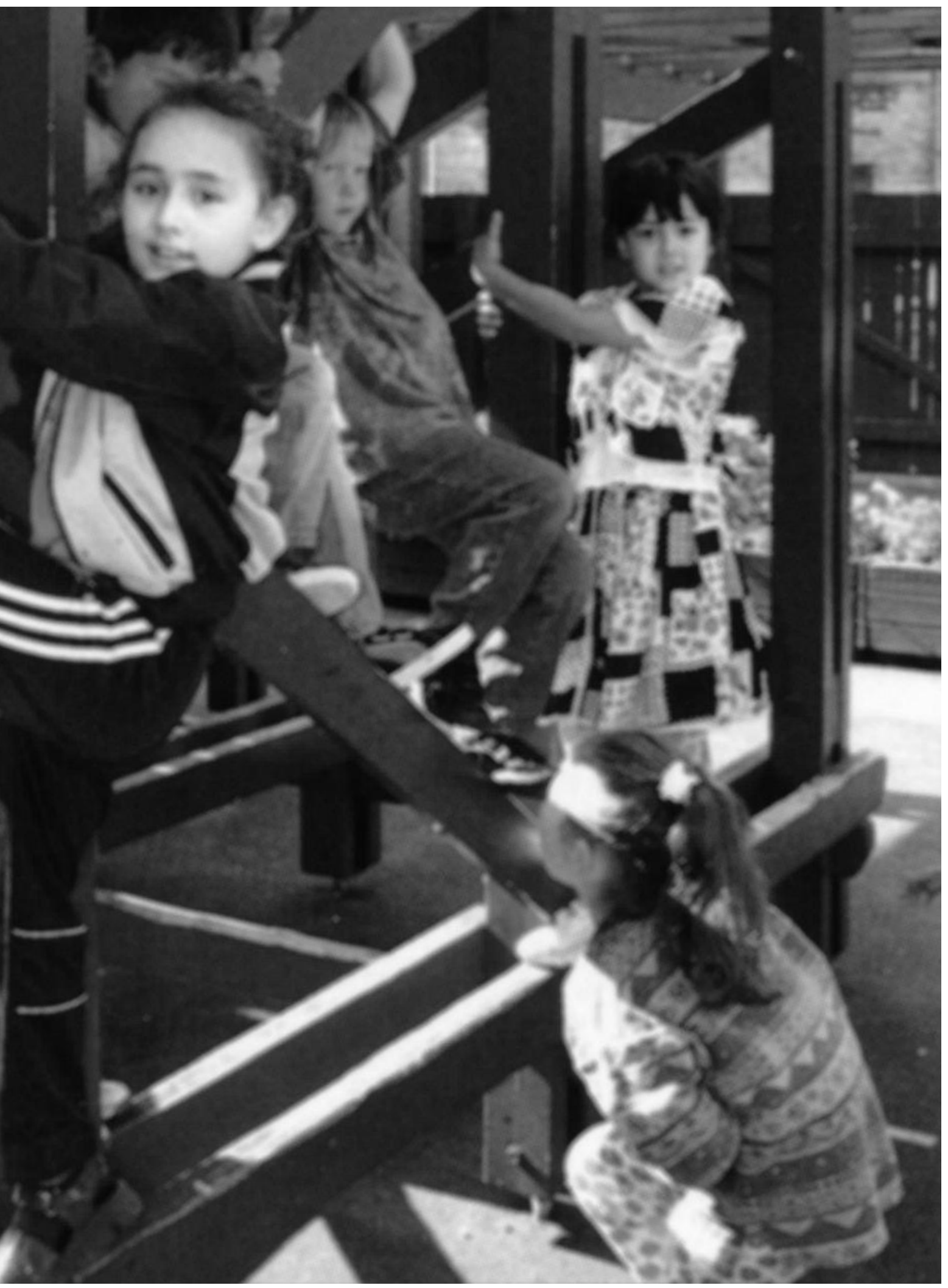


Også samhandlingen barna imellom forklares ut fra samfunnets kjønnsnormer. En svensk undersøkelse av elever i l. klasse viste, at guttene utfører dominanshandlinger dobbelt så mange ganger som jenter (Käller 1990). Når jentene utøver dominans overfor andre, er det som regel overfor andre jenter. Jentene er altså langt oftere gjenstand for dominans, både fra gutter og jenter. Mens jentenes dominansteknikker er subtile og normative (f.eks hevde lærerens regler overfor medelever), er guttenes oftere fysiske og regelbrytende. Jenter gir ofte uttrykk for engstelse for guttenes fysiske og aggressive framferd, og de utvikler strategier for å unngå den, f.eks ved ikke å stå i veien for en hoiende guttehorde eller ignorere plagsomme gutter (Berentzen 1980, Pedersen \& Reisby 1991, Gulbrandsen 1994). Når de nærmer sig puberteten, kan guttene hevde sig overfor de mer kroppslig utviklede jenter ved å trekke på kulturens kvinnebilder, der de prøver å at redusere dem til kropp og kjønn. Undersøkelser av jenter og gutter i ungdomsskolen viser hvordan jenter svinger mellom å eksponere deres kropp for å demonstrere at de er voksne - og å skjule den for ikke å få sexistiske kommentarer fra guttene (Jensen m.fl. 1984, Lees 1986, Bjerrum Nielsen 1988). Den asymmetriske maktrelasjonen mellom kjønnene blir på denne måten også til en del av skolens skjulte læreplan (Kruse 1995).

Styrken ved kjønnsmaktanalysen er at den synliggjør ulikhet og forfordeling mellom kjønnene, og at den setter spørsmålet om individuell rettferdighet i sentrum. Svakheten ved den er at jentene bare sees som passive ofre for lærerens forskjellsbehandling og guttenes dominans. Forklaringen får også lett et noe konspiratorisk skjær - det forklares ikke hvorfor lærerne forskjellsbehandler eller hvorfor guttene søker makt. Den er et eksempel på en strukturfunksjonalistisk forståelse av hvordan sosiale strukturer reproduseres: Jenter og gutter tilpasser sig motstandsløst lærernes og foreldrenes normer og forventninger. Forhol- det mellom gutter og jenter sees som en direkte avspeiling av forholdet mellom voksne menn og kvinner. Men barn er ikke bare passive mottakere av den sosiale orden. Det framgår jo tydelig av klasseromsstudiene, at barna også tar aktivt del i konstruksjonen av kjønn, og at deres egne innspill er viktige elementer i etableringen av klasserommets kjønnede samhandlingsmønstre.

\section{Kjønnsidentitet og kjønnssosialisering}

Denne forklaringsmåten legger vekt på at det som skjer i klasserommet, er en del av en psykologisk og kulturell prosess som har sin start lenge før eleven kommer inn i klasserommet, og som fortsetter både innenfor og utenfor klasserommets fire vegger. Barn utvikler en identitet som jenter og gutter allerede i toårsalder. Gjennom barndommen og ungdommen ser vi hvordan de aktivt arbeider med å markere 'grenser' til det andre kjønnet (Davies 1989, Thorne 1993). Guttene rotter seg sammen og erter jentene, og jentene har hemmeligheter som bare jenter får vite om. Uttrykkene for dette grensearbeidet og hvor viktig det er å trekke grenser, varierer med alder, kjønn og kontekst. Grensemarkering ser ut til å være sterkest og minst fleksibel $\mathrm{i}$ alderen fra 5 til 12 år. Gutter markerer som regel sterkere grenser mot jenter enn omvendt og begge kjønn er mer opptatt av grensemarkering når de opptrer i grupper og $\mathrm{i}$ institusjonelle sammenhenger (f.eks. skolen) enn de er i mer uformelle og personlige sammenhenger (f.eks. i lek hjemme). En jente og en gutt som ignorerer hverandre i skolen, kan ofte være fine venner hjemme hvor de bor. Disse sosiale prosessene bidrar til å skape ulike kjønnskulturer - en jente- og en gutteverden med ulike regler og ulike kulturelle og moralske verdier. I et psykologisk perspektiv kan de også sees som prosesser som er med på å skape ulike kjønnsidentiteter, en følelse av hvem man er som person. I stedet for å se denne atferden som uttrykk for en tillært kjønnsrolle legger kultur- og identitetsperspektivet vekt på at barna ar- 
beider aktivt med på sin egen kjønnssosialisering, og at det som skapes, ikke bare er normsett, men opplevd individuell identitet.

To ganske forskjellige jente- og gutteverdener toner fram $\mathrm{i}$ disse undersøkelsene fra 1980-tallet: ${ }^{2}$ Jentene liker best å være sammen to og to, hvor de kan gi hverandre personlig oppmerksomhet og ha hemmeligheter sammen, mens mange gutter trives bedre i større og ofte hierarkisk strukturerte grupper. Guttenes grupper er rammen om et handlingsfellesskap, som kan gi dem en opplevelse av styrke og solidaritet. Mens jenter som regel kan snakke med hverandre i timevis (det første de gjør når de kommer hjem fra skolen, er å ringe bestevenninnen og prate videre), der vil guttene heller ha handling og ikke så mye prat - og slett ikke om følelser og holdninger. Jenter liker samarbeid og gruppearbeid bedre enn gutter, mens guttene motiveres mer av konkurranse. Jenter og gutter ser ut til å være orientert mot ulike aspekter av omverdenen: Jentene er opptatt av menneskelige relasjoner og sosiale forhold, gutter av mer upersonlige ting, individuelle bedrifter og facts. Klasseromsforskningen har vist, at jentene blir mer aktive, når menneskelige og sosiale emner kommer opp, eller når undervisningstemaet får en personlig vinkling, mens den største guttedominans finnes i fysikktimene, og når det snakkes om politikk og historie (Sjøberg \& Lie 1984, Staberg 1993). Når jenter og gutter forteller om egne opplevelser i klassen legges fokus ulike steder: Gutter forteller ofte poengtert om dramatiske eller morsomme opplevelser, og de andre gutter prøver å overgå historien ved å fortelle noe, som er enda mer dramatisk eller morsomt. Jentene forteller heller om små opplevelser fra dagliglivet, og de andre jenter tar ordet for å si at de har opplevd akkurat det samme. De bruker samtalen til å understreke likhet i erfaringer, mens guttene bruker den til å markere forskjellighet. I klasser, hvor jenter dominerer forløper samtalen ofte lidt annerledes, hva angår både form og innhold - den blir mindre konkurransepreget, mer dagligdags og hverdagsnær.

Sett i dette perspektivet er jentenes samarbeidsvillige stil ikke nødvendigvis et uttrykk for passivitet eller prektighet, eller for at de ikke kommer til orde, men derimot for deres relasjonelle identitet som gjør at de både er mer interesserte $\mathrm{i}$ å forholde seg til andre mennesker og mer kompetente i å ta de andres perspektiv og å forstå deres ønsker og behov. Jenter har 'sosiale antenner' (Hjort 1984), og de trener ikke minst disse antennene $\mathrm{i}$ sine venninneforhold, hvor de utforsker relasjoner og kontinuerlig gjennomlever svikets fortvilelse og forsoningens sødme. Guttenes mer selvhevdende og vidløftige oppførsel i klassen kan på sin side forbindes med deres mer hierarkiske og konkurransebetonte sosiale liv, hvor det å få offentlig beundring og anerkjennelse fra guttegruppen øker selvfølelsen mer enn det å inngå i intime relasjoner med særlig utvalgte, og hvor demonstrasjon av overlegenhet over for jentene synes å være et sentralt element i deres kollektive maskuline identitet. Klasseromsstudiene har vist, at især middelklassegutter oppfatter den offentlige klassesamtalen som en selvfølgelig arena for konkurranse med andre gutter, mens jentene ofte har et mer ambivalent forhold til å markere seg individuelt i klasseoffentligheten. De reagerer negativt på konkurransen, og individuell markering kan oppleves som et svik av fellesskapet med venninnen (Lauersen 1984, Hjort 1984, Bjerrum Nielsen 1988, Rasmussen 1989). Katrin Hjort (1984), som har undersøkt jentene ved overgangen fra grunnskolen til den videregående skolen, mener at jentene taper terreng på grunn av de nye sosiale betingelser og de nye faglige krav i retning av mer abstrakt og upersonlig kunnskap, mindre personlige relasjoner til lærerne, mere konkurranse mellom elevene, kort sagt en undervisningssituasjon som gir et smalere nedslagsfelt for jentenes sosiale antenner. 
Jenters og gutters ulike sosiale orientering kan også kaste lys over den måten de opponerer mot skolen på. Ungdomsforskere har påpekt kjønnstypiske motstandsformer og maktstrategier i forhold både til læreren og medelever. Her er det tydelig, at klassebakgrunn også spiller inn. Middelklasseguttene kan bruke sin verbale og personlige sikkerhet til å latterliggjøre lærere og elever, uten at det rammer deres gode karakterer (Bjerrum Nielsen \& Larsen 1985). Noen arbeiderklassegutter opponerer mot skolens middelklassekultur gjennom en bevisst uansvarlig og machoistisk oppførsel - en strategi som fører til, at de dropper tidlig ut av skolen og dermed besegler deres klasseskjebne. Disse guttene befinner seg nederst i det mannlige statushierarkiet og hevder deres maskulinitet bl.a. gjennom kvinneforakt (Willis 1977, Connell 1989). Niels Kryger (1988) har vist, hvordan denne machoisme hos 'de skrappe drenge' får spesielle vilkår i en periode, hvor kjønn er under endring: Arbeiderguttene, hvis tradisjonelle arbeidsplasser forsvinner, raser mer eller mindre avmektig mot de nye middelklassekvinner, som er på vei opp, hva enten de framtrer i form av likestillingsmoraliserende lærere eller som dyktige og verbalt selvsikre jenter i klassen.

På samme vis kan jentenes relasjonelle kompetanse brukes til å skaffe dem fordeler. Deres sosiale antenner kan skaffe dem frirom i skolen f.eks. ved at de nøyaktig vet hvilken kroppsholdning de skal innta for at læreren skal tro at de følger med, eller presis hvor høyt de kan prate sammen om private ting uten at læreren griper inn. Noen jenter bruker sin kunnskap om relasjoner til å føre personlig krig mot lærerne og skolen, blant annet ved hele tiden å komme akkurat så lite for sent at læreren ikke riktig kan gripe inn, men bare blir irritert til vanvidd. Andre strategier er å sende ut små signaler, som ikke er til å misforstå, om hvor grenseløst kjedelig de synes undervisningen er, eller å bli sure i ukevis på en lærer som har fornærmet dem. Lærere opplever at mange jenter er svært vanskelige å ha med å gjøre, og noen sier rett ut at de ville ha fortrukket å undervise gutter framfor jenter i denne alderen (Davies 1984, Jensen m.fl. 1984, Lees 1986, Bjerrum Nielsen 1988, Öhrn 1991).

Synliggjørelsen av jenters og gutters livsverden og identitet viser oss at kjønnets sosiale reproduksjon er mer innfløkt enn det rolle- og maktteorier antar. Men beskrivelsene har også blitt kritisert for å gi et for stereotypt bilde av gutter og jenter. Det er lite fokus på interaksjon mellom kjønnene, variasjon innenfor hver kjønnsgruppe, eller mangfoldet $\mathrm{i}$ den måten den enkelte jente eller gutt kan opptre på. Behovet for å synliggjøre kjønnet som var blitt borte i pedagogikken, gjorde at en del av 1970- og 80tallets forskning fikk en tendens til å overdrive kjønn og se bort fra andre forskjeller. Som mange forskere har påpekt i ettertid, finnes det ikke én femininitet og én maskulinitet, men mange femininiteter og maskuliniteter - og det foregår en stadig kamp om hegemoni mellom dem innbyrdes (Connell 1995). I stedet for å forstå kjønnsidentitet som en stabil psykisk struktur kan kjønn sees som en rekke skiftende posisjoner i forhold til dominerende kulturelle fortellinger om kjønn.

\section{Kjønnskonstruksjoner og forbandlinger}

Innen for denne forklaringsmåten er spørgsmålet om hvem man er alltid et åpent spørsmål med skiftende svar, avhengig av hvilke posisjoner som aktualiseres i samhandlingen. Kjønn er ikke noe man er, men noe man gjør. Kulturens fortellinger om kjønn begrenser og former de posisjoner som finnes for henholdsvis jenter og gutter, både når det gjelder den måten de forstår seg selv på og den måten læreren fortolker deres atferd. Men i og med at makten ligger i språket, og ikke bare hos de dominerende grupper, så betyr det også at elevene ved 'å gjøre kjønn' kontinuerlig forhandler om, bekrefter eller opponere mot de kjønns-posisjoner, som tilbys i klasse- 


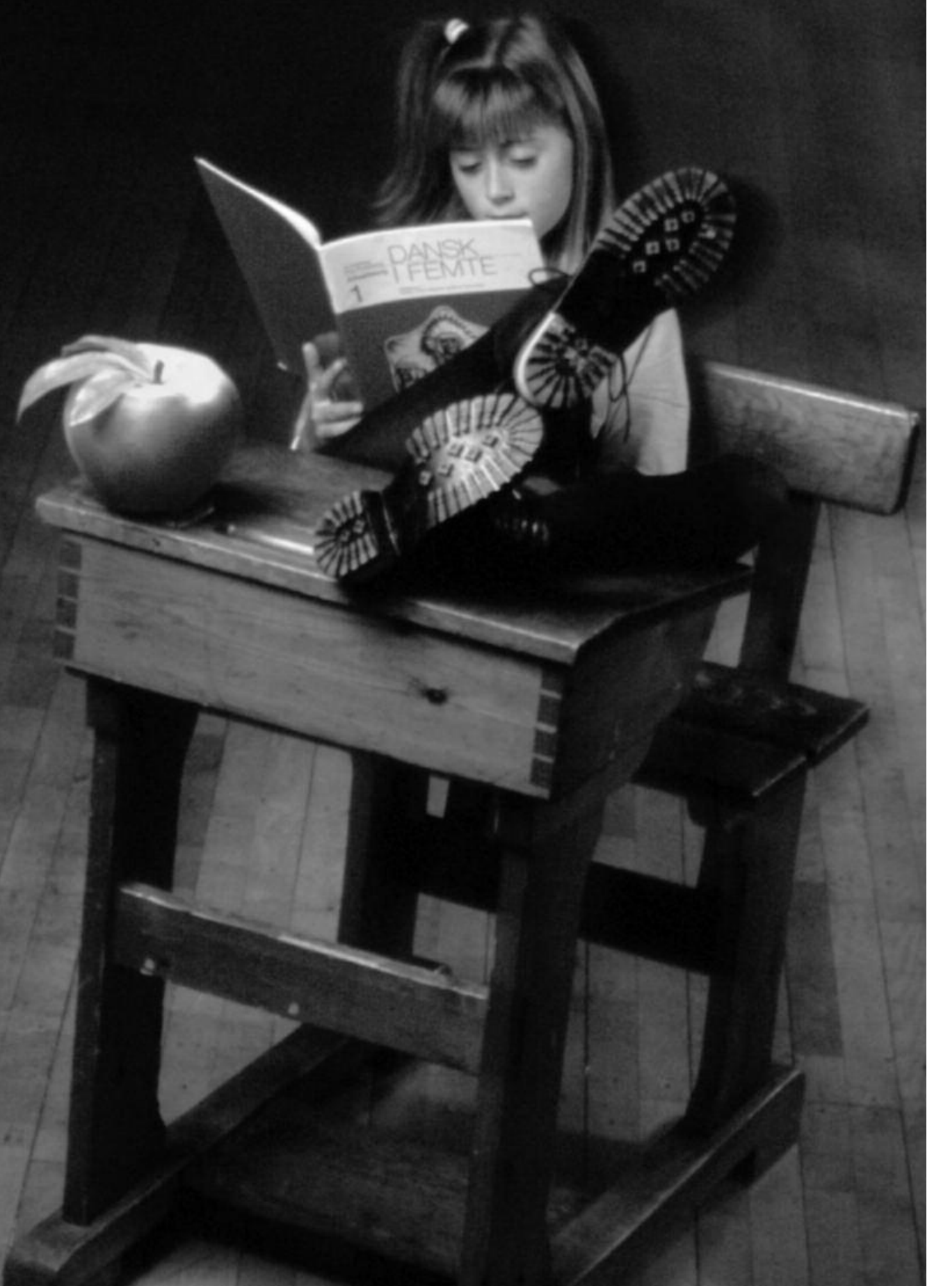


rommets samhandling (se f.eks. Davies 1989, 1993, Walkerdine 1990, Søndergaard 1996).

Det er ikke bare personer som 'făr kjønn' gjennom språket, men også mål, verdier, normer, egenskaper og aktiviteter. Tilsynelatende nøytrale begreper som skole, undervisning, kunnskap, barn, utvikling, har et kjønnet innhold som er med på å gjøre jentene til bipersoner og guttene til hovedpersoner. 'Skolen' er et rom som usynliggjør og marginaliserer jenter fordi det struktureres av en 'fortelling' om et 'barn' som er rasjonelt, nysgjerrig, undersøkende, lekende, kreativt, morsomt, og sjarmerende frekt mot de voksne. Det sies ofte at jenter er mer modne og ansvarlige enn gutter, men vi er ikke helt overbeviste, for i vår kultur måles utvikling som uavhengighet av andre. Dette gir opplevelsen av jentenes relasjonelle kompetanse og sosiale orientering en bismak av avhengighet og konformitet. Samtidig er det akkurat dette, vi forventer av jentene - fordi vi antar at de er forskjellige fra gutter. Den engelske kvinneforskeren Valerie Walkerdine har vist, hvordan lærere kan oppfatte en urolig og faglig svak gutt som egentlig mer intelligent enn en dyktig og samarbeidsvillig jente - ut fra et rasjonale om, at gutten sikkert kjeder seg og savner utfordringer (Walkerdine 1989). Eksemplene avslører at vi har to ulike standarder for modenhet hos jenter og gutter, og ettersom den generelle oppfattelsen av barns utvikling er hentet fra guttestandarden, så blir utvikling hos jenter tvetydig, og hos gutter paradoksal: Deres sosiale umodenhet forstås som det endegyldige beviset på at de er på vei til å bli store. Som Valerie Walkerdine sier, så er de kulturelle narrativer om et vellykket barn og en vellykket jente på kollisjonskurs.

På samme måte er våre begreper om undervisning og utdanning historisk sett modellert over en borgerlig mannlig norm. Skolen er et offentlig rom, hvor der ikke skal blandes inn for mye personlig og privat, og hvor det som gjelder er å markere seg som individ i konkurranse med andre. Kommunikasjonsformen og kunnskapsbegrepet er hentet fra den offentlige sfæren. Katrin Hjort (1984) har beskrevet 'skolekoden' i videregående skole som

"...en sjov blanding af spillereglerne for den borgerlige offentlighed, den økonomiske kalkule, den naturvidenskabelige/positivistiske metode og den matematiske logik (...). Skolekoden sorterer de faglige indlæg (...). Den viden, der ikke kan bringes på formlen for det objektive, det saglige, det logiske, det rationelle, det dokumenterede henvises til kassen for det subjektive og usaglige og ulogiske og irrationelle og postulerende. Den kasse med emotionelle og personlige indlæg som man ikke kan tage alvorligt i en faglig debat” (90 og 93).

Men mange av de områder jenter er opptatt av, kan jo nettopp ikke bringes på denne rasjonelle og målbare form, mens guttenes interessesfære kanskje lettere kan det. Jentene lider altså et identitetstap, når de beveger seg fra den 'kvinnelige' familiesfære, hvor de har individualitet og over $\mathrm{i}$ den 'mannlige' institusjonelle sfære, hvor de har kjønn. Derfor fremtrer jenter ofte så merkelig anonyme i skolen, og det er en anonymitet, som øker dess mer tradisjonelt fagorientert skolen er. På den måten blir skolen et rom som tendensielt gjør gutten til 'eleven' og jentene til 'de andre', og som også hierarkiserer guttene etter klassebakgrunn. Forskjellen på jentene og arbeiderguttene er imidlertid at reaksjonene på denne marginalisering er mer synlige og høylytte hos guttene enn hos jentene, og at vi derfor får en usynliggjøring av jentenes problemer med marginaliseringen, som ikke i så høy grad rammer guttene.

Nå er det jo mange som hevder at skolen i dag domineres av 'kvinnelige' samværsformer og aktiviteter heller enn av 'mannlige': sitte stille, samarbeide, ta hensyn, verbalisere sine følelser. Kvinnelige autoritetsformer - 'omsorgsmakt' med appell til skyldfølelse, 
fornuft og ansvarlighet - har avløst farsautoriteten i skolen (Kryger 1991). Der er neppe noen tvil om at de mange kvinnelige lærere har tilført skolen elementer av en kultur som tradisjonelt har vært knyttet til familiesfæren. Men også de kvinnelige lærere er bærere av kulturens kjønnsnøytrale kategorier for, hva et ideelt barn og riktig utvikling er. Vi ser det f.eks. i deres ambivalens over for bråkete gutter, som på den ene side gjøres til et problem og utsettes for endeløse moralprekener, men som samtidig lykkes med å sjarmere lærerne på en helt annen måte enn bråkete jenter (Bjerrum Nielsen 1988, Altani 1995, Andersen \& Kampmann 1996). Det er faktisk spesielt de kvinnelige lærere som gir uttrykk for, at de har vanskelig for å godta 'jentetullet', intimiteten og venninnekonfliktene i jentegruppen. De syns jentene burde bruke kreftene på noe mer konstruktivt - mens de mannlige lærere knapt bemerker, hva som foregår (Reisby 1991a).

Det viktige ved dette perspektivet er at det får fram det flytende og ustabile i det vi kaller kjønn og hvordan det hele tiden er avhengig av å bli konstruert på nytt. Men det sterke fokus på hvordan kjønnet er til stede i språket og i kulturell samhandling for øvrig, har ført til en underbetoning av at det faktisk også er til stede i mennesker. Det mangler et tidsperspektiv knyttet til hvordan utvikling og forandring skjer i det enkelte individ. Når jenter eller gutter 'gjør' kjønn innen for beslektede diskurser, 'blir' de faktisk også jenter og gutter på beslektede måter. Det er altså viktig å være på vakt både overfor sosialiseringsforskningens tendens til å overdrive likheter og sammenheng, og overfor konstruksjonsperspektivets tendens til å overdrive forskjeller og fragmentering.

\section{NYE OPPSKRIFTER PÅ KJØNN?}

Klasseromsstudiene stammer fra 1970- og 80-tallet. Passer årtusenskiftets jenter og gutter fortsatt til disse beskrivelser? I en periode hvor vi opplever store sosial forandringer $\mathrm{i}$ forholdet mellom kjønnene, kan det settes spørsmålstegn ved alle tre forklaringsmodeller: $\mathrm{Er}$ dominans/underordningsmodellen fortsatt relevant for å forstå kjønnsforholdet i dag? Er kjønnenes psykologi og kultur virkelig så distinkt forskjellige? Er betydningen av femininitet og maskulinitet ikke ved å bli mindre stabil?

Nyere undersøkelser om dette kan tyde på at $\mathrm{i}$ hvert fall noen av jentene setter sammen kjønnet på litt andre måter enn tidligere. ${ }^{3}$ En ny type av jenter har blitt bemerket spesielt i videregående skoler med elever som kommer fra hjem hvor både mor og far har høyere utdanning: Aktive, kritiske og reflekterte jenter som engasjerer seg i den verden de lever i - f.eks ved å delta i politiske grasrotaktiviteter eller skoledemokratiet. At en typisk representant for Natur og Ungdom er en jente har blitt helt selvfølgelig for oss. De ytterst få studier av klasseromsinteraksjon som finnes fra 1990-årene, viser at en del jenter i videregående skole framtrer mye mer aktivt og selvhevdende, men også at dette ser ut til å være geografisk og sosialt betinget. De stille jenter har altså ikke forsvunnet, men de overdøves i dag ikke bare av gutter, men også av mer frimodige og selvsikre medsøstre - noe som for øvrig gir grobunn for nye splittelser jentene imellom. Det som nesten er mest interessant er imidlertid at disse 'nye' jentene ser ut til å kombinere tradisjonelt kvinnelige og tradisjonelt mannlige trekk på en måte som viser at relasjonell orientering ikke trenger å utelukke aktivitet, ambisjoner og utadrettet engasjement. Det ene øyeblikk markerer jentene seg med den største selvfølgelighet i klasseoffentligheten, det neste øyeblikk sitter de med armen om halsen til venninnen, intenst opptatt av relasjoner og nærhet. De kan kle seg seksuelt utfordrende, men krever samtidig å bevare kontrollen over situasjonen. Og venninnene prioriteres bevisst framfor kjæresteforhold til gutter, som de anser for farlige for deres selvstendighet og egen identitet. No- 
en forskere har i dette sett en ny sosial kompetanse til å integrere prestasjonsorientering og intimitetsorientering, engasjement og nytelse - mens andre har antydet omkostninger i form av økt behov for selvkontroll og dermed angst for å slappe av og gi seg hen.

Hvordan reagerer guttene på disse fremadstormende middelklassejentene? Det vet vi mindre om. Noen undersøkelser gir inntrykk av at guttene endrer seg langsommere, og at de reagerer mer defensivt på den nye situasjonen. Men undersøkelser av unge voksne menn tyder likevel på at en del av dem (typisk de som har vokst opp i moderne middelklassefamilier) begynner å ha et mer integrert forhold til omsorgsverdiene. Hvordan disse tingene slår ut blant de yngre barna og om det eventuelt har endret samhandlingsmønsteret i klasserommet har stort sett ikke blitt undersøkt forskningsmessig (se dog Hjort 1987). I en liten undersøkelse jeg selv holder på med i en barneskoleklasse (med skolestart i 1992), ser jeg nok en noe større variasjon $\mathrm{i}$ måtene man kan være gutt eller jente på enn tidligere - ikke alle guttene er like konkurrerende og ikke alle jenter har relasjonskompetanse. $\mathrm{Og}$ jeg ser kombinasjonene: Individualistisk oppførsel hos jenter kan gå hånd $\mathrm{i}$ hånd med relasjonskompetanse og beredskap til å være småtanter. Guttehierarkiet kan romme gutter som gråter, og gutter som trøster istedenfor å erte (Bjerrum Nielsen 1994). Men det er vanskelig å si hvor utbredt disse fenomenene er.

Men hvis kjønn både er mer mangfoldig - og der til under kontinuerlig forandring $\mathrm{i}$ de nye barne- og ungdomsgenerasjonene så må dette få konsekvenser for de pedagogiske strategiene. Ellers kan de, mot sin hensikt, komme til å fastfryse kjønnet i stedet for å endre det.

\section{USYNLIGGJØRELSE ELLER OVERDRIVELSE AV KJØNN}

De pedagogiske strategiene har i løpet av de siste 15 årene beveget sig fra en jentekompensatorisk pedagogikk, som har satset på å få det tradisjonelle faglige innholdet til å framtre mer gjenkjennelig og interessant for jentene, over en jentevennlig pedagogikk, som har oppvurdert jentenes spesielle verdiorientering og siktet mot å femininisere skolens innhold, og til en likeverdsfremmende pedagogikk for begge kjønn (Pedersen \& Reisby 1991, Kruse 1995). Målet er her, å styrke et bredt spekter av kompetanser hos begge kjønn, anerkjenne forskjellighet, men motarbeide at en slik forskjellighet gir ulikhet $\mathrm{i}$ status. De pedagogiske strategiene har hatt en viss tendens til enten å usynliggjøre eller å overdrive kjønn. Noen ganger begge deler, f.eks i den typen skolebøker hvor alle som snekrer og klatrer, framstilles som hunkjønn, mens alle som baker og vasker, framstilles som hankjønn. Her usynliggjøres på den ene siden det faktiske kjønnsrollemønsteret, samtidig som den konsekvente omvendingen overdriver betydningen av kjønn (gutter kan faktisk også snekre, jenter også bake). Overdrivelse av kjønn finner vi også på den måten at de fleste likestillingspedagogiske strategier paradoksalt nok tar kjønn for gitt - hva enten de ønsker å kompensere for kvinnelighet (den jentekompensatoriske strategien), ser de kvinnelige verdier som de mest verneverdige (den jentevennlige strategien) eller foreslår å blande 'mannlige' og 'kvinnelige' egenskaper til en androgyn størrelse (den likeverdsfremmende strategien). At disse egenskaper i det hele tatt defineres som maskuline og feminine tas med på kjøpet. I alle tilfeller tas det for gitt at det finnes noe mannlig og kvinnelig og at det alltid må være slik. Uenigheten går på om man skal velge det mannlige, det kvinnelige eller begge deler. Vi overser den muligheten at det vi i dag kaller mannlig og kvinnelig, kunne deles opp på andre måter og kombineres på skiftende og mangfoldig vis. Dermed bygges forandringsprosjektet på et fundament av tradisjonell kjønnsorden.

En mindre dualistisk kjønnsoppfattelse 
fjerner ikke kjønnsforskjellene, men kan kanskje gjøre den til en mer mangfoldig og variable affære? Når en grense forsvinner, så făr de som hørte til på hver side av grensen, mulighet for å bli mer forskjellige innbyrdes. Vi vil ikke få kvinnelighet og mannlighet som to atskilte kategorier, men mange forskjellige måter å være kvinne og mann, jente og gutt på. Det vil kunne gi kvinner og menn større muligheter for selv å utforme sitt kjønn, hvis ikke dualismen var den dominerende tankefiguren. Og det ville gjøre det vanskeligere å knytte kjønn til en sosial maktstruktur.

Men så er jo spørsmålet om en slik respekt for individuelle forskjeller, også når det gjelder utformning av kjønn, risikerer ennå engang å skjule kjønnet? Sende oss tilbake til reformpedagogikkens illusjon om det kjønnsnøytrale barn, som bare er definert gjennom sin individualitet? Hvor vi ignorerer det faktum at sosiale maktstrukturer og hierarkier kan sette sig igjennom, selvom de er språklig og ideologisk tilslørt? Dilemmaet her dreier sig om på den ene side ikke å redusere uttrykk for sosiale maktstrukturer til individuelle forskjeller, og på den andre siden ikke å redusere individualitet til sosiale kategorier. $\AA$ beskrive elever gjennom så grove sosiale kategorier som kjønn, sosial klasse og etnisk tilhørighet gjør vold på den enkeltes unike identitet. Men uten disse kategorier vil vi på den andre siden miste forståelsen for utviklingens sosiale betingelser. Da fortoner noe som egentlig har å gjøre med kulturelle og sosiale betingelser, seg som barnets helt tilfeldige personlighet. Dermed fastfryser vi sosiale forhold og gjør det vanskelig for undertrykte grupper å samle seg for å bekjempe forskjellsbehandling og urettferdighet. Noe ganger er det en styrke for jentene å definere seg som jenter, utsatt for samme type usynliggjøring og marginalisering. Andre gange vil det være en begrensning for deres utviklingsmuligheter å bli sett og definert $\mathrm{i}$ kraft av deres kjønn. Vi er derfor nødt til både å synliggjøre kjønn - og samtidig ikke

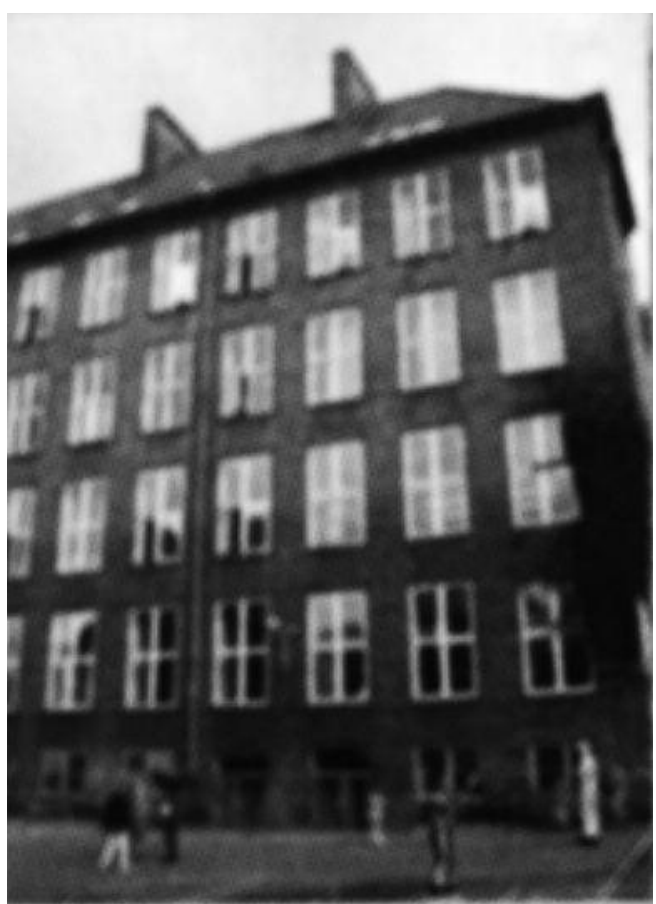

Foto: Anders Rosenberg 
overdrive det. Et dobbeltblikk av forskjell og likhet er ikke minst nødvendig i en periode hvor kjønn forandrer seg så raskt som det gjør i vår tid.

\section{Noter}

1. Denne artiklen er skrevet til en norsk antologi Kjønn og likestilling i skolen, redigert av Gunn Imsen. Boka kommer ut 8.mars 2000 på forlaget ad Notam, Gyldendal. I nærværende utgave er det foretatt noen mindre endringer for å tilpasse den til danske lesere. Artiklen er for øvrig en sterkt forkortet, oversatt og delvis omskrevet versjon av artiklen 'Sophie og Emile i klasseværelset' som er trykt i Jens Bjerg (red.) (1998): Pedagogik - en grundbog til et fag, Hans Reitzels forlag, København.

2. Se f.eks Lever 1976, Best 1983, Whyte 1983, Hjort 1984, Jensen m.fl.1984, Paley 1984, Connell 1989, Gilligan m.fl.1990, Andersen \& Kampmann 1996, Bjerrum Nielsen 1984, Lauersen 1984, Rasmussen 1988, Bjerrum Nielsen \& Rudberg 1989, Davies 1989, Chodorow 1989, Reay 1991, Thorne 1993. En kommenteret oversigt over en del nordisk og udenlandsk litteratur findes i Andersen \& Kampmann 1991.

3. Nyere undersøkelser se f.eks. Schultz Jørgensen 1990, Bengtsson 1991, Drotner 1991, Kleven 1992, Bjerrum Nielsen \& Rudberg 1994, Søndergaard 1996.

\section{REFERENCER}

- Altani, C. (1995): Primary school teachers' explanation of boys' disruptiveness in the classroom: a gender-specific aspect of the hidden curriculum, in Mills, S. (ed.) Language o Gender. Longman, London.

- Andersen, P.Ø., Kampmann, J. (1996): Børns legekultur. Munksgaard-Rosinante, København. - Best, R. (1983): We've all got scars: What Boys and Girls Learn in Elementary School. Indiana University Press, Bloomington.

- Bengtsson, M. (1991): Könssocialisation och social förandring. Psykologi i tillämpning, 1, Institutionen för tillämpad psykologi, Lunds Universitet. - Bjerrum Nielsen, H. (1981): Små piger, søde piger, stille piger, in Sosiologi $i$ dag 5-6. Gjenopptrykt i Klette, K. (1998). Klasseromsforskning på norsk. Ad Notam/Gyldendal, Oslo. - Bjerrum Nielsen, H. (1988): Jenteliv og likestillingslare. Cappelen, Oslo.
- Bjerrum Nielsen, H. (1994): Boys and Girls From Grade One to Grade Nine, in Social Construction of Gender in Children's Worlds. Arbeidsnotat 3, Senter for kvinneforskning, Universitetet i Oslo.

- Bjerrum Nielsen, H., Larsen, K. (1985): Piger og drenge $i$ klasseoffentligheden. Pedagogisk forskningsinstitutt, rapport $\mathrm{nr} .2 / 85$, Universitetet i Oslo.

- Bjerrum Nielsen, H., Rudberg, M. (1989): Historien om jenter og gutter. Universitetsforlaget, Oslo.

· Bjerrum Nielsen, H., Rudberg, M. (1994): Psychological Gender and Modernity. Universitetsforlaget, Oslo.

- Brock-Utne, B., Haukaa, R. (1980). Kunnskap uten makt. Universitetsforlaget, Oslo.

- Chodorow, N. (1989): Feminism and Psychoanalytic Theory. Yale University Press, New Haven. - Clarricoates, K. (1978): Dinosaurs in the classroom - a re-examination of some aspects of the 'hidden' curriculum in primary schools, in Women's Studies Inernational Quarterly 1: 353-364.

. Connell, R. W. (1989): Cool Guys, Swots and Whimps: the interplay of masculinity and education, in Oxford Review of Education 15,3: 291-303. - Connell, R.W. (1995): Masculinities. Polity Press, Oxford.

- Corson, D. (1993): Language, Minority Education and Gender. Multilingual Matters. Ontario Institute for Studies in Education, Toronto.

- Davies, B. (1989): Frogs and Snails and Feminist Tales. Preschool Children and Gender. Allen and Unwin, Sydney.

- Davies, B. (1993): Shards of Glass. Children Reading and Writing Beyond Gendered Identities. Allen and Unwin, Sydney.

- Davies, L. (1984): Pupil Power. Falmer Press, London.

- Delamont, S. (1980): Sex Roles and the Schools. Methuen, London.

- Drotner, K. (1991): At skabe sig selv-ungdom, estetik, pedagogik. Gyldendal, København.

- Einarsson, J., Hultman, T. (1984): Godmorgen pojkar och flickor. Liber forlag, Stockholm.

- Gilligan, C., N.P. Lyons, Hanmer, T.J. (eds.) (1990): Making Connections: The Relational Worlds of Adolescent Girls at Emma Willard School.

Harvard University Press, Cambridge.

- Good, T., J. Sikes, Brophy, J. (1973): Effects of teacher sex and student sex in classroom interaction, in Journal of Educational Psychology 65, 74-87. - Gulbrandsen, L.M. (1994): Blant hester og gorillaer i skolegården: Utvikling i en kjønnet kultur, in Psyke \& Logos 15,1: 109-124. 
. Hjort, K. (1984): Pigepedagogik - ? Gyldendal, København.

- Hjort, K. (1987): Piger og drenge - om konssocialisering $i$ 80'erne. Gyldendal, København.

- Kelly, A. (1988): Gender differences in teacherpupil interactions: a meta-analytical review, in Research in Education 39, 1-23.

- King, R. (1978): All Things Bright and Beautiful? Wiley, Chichester.

- Kleven K. V. (1992): Jentekultur som kyskhetsbelte. Universitetsforlaget, Oslo.

- Kristiansen, M. (1980): 'De stille piger'. Kontext 40 .

· Kruse, A.M. (1989): 'Pigeskole eller fællesskole? Debatten omkring århundredeskiftet', in Hilden, A., Kruse A-M. (red.): Pigernes skole. Klim, Århus. - Kruse, A-M. (1995): Pigepædagogik og drengepædagogik - debat, praksis og perspektiver. Cekvina Arbejdsnotat 24, Århus Universitet. En utvidet engelsk oversettelse finnes i Women's Studies International Forum 19,4: 429-445.

- Kryger, N. (1988): De skrappe drenge - og den moderne padagogik. Unge Pxdagoger, København.

- Käller, K.L. (1990): Fostran til andrarang. Acta Universitetis Upsaliensis. Uppsala Studies in Education nr. 34 .

- Lauersen, E. (1984): 'Høje' piger - 'lave' drenge: Social differentiering, karakterer og elevsituation $i$ gymnasiet. Serie om uddannelsesforskning nr. 8, Aalborg Universitetsforlag.

- Lees, S. (1986): Loosing Out: Sexuality and adolescent girls. Hutchinson, London.

- Lever, J. (1976): Sex Differences in the Games Children Play, in Social Problems 23: 478-487.

- Paley, V. (1984): Boys and Girls: Superheroes in the Doll Corner. University of Chicago Press.

- Pedersen, G., Reisby, K. (red.). (1991): Ligevard - Mangfoldighed: Om ligestilling i skolen. Danmarks Lærerhøjskole, Århus.

- Rasmussen, P. (1988): Dygtige drenge: Drenge med høje karakterer $i$ gymnasiet. Aalborg Universitetscenter.

- Reay, D. (1991): Intersections of Gender, Race and Class in the Primary School. British Journal of Education 12,2: 163-182.

- Reisby, K. (1994): 'Køn og pædagogik i et udviklinsperspektiv', in Unge Padagoger 6: 8-18.

- Schultz-Jørgensen, P. (1990): Er en ændret pigerolle på vej?', in Jacobsen, H., Højgaard, L. (red.) Skolen er køn. Ligestillingsrådet, København.

- Sjøberg, S., Lie, S.(1984): 'Myke' jenter $i$ 'harde' fag? Universitetsforlaget, Oslo.

- Spender, D., Sarah, E. (1980): Learning to Lose: Sexism and Education. The Women's Press, London.
- Staberg, E-M. (1993): Olika världar skilda värderingar: Hur flickor och pojkar möter högstadiets fysik, kemi och teknik. Pedagogiska institutionen, Umeå Universitet.

- Stanworth, M. (1983): Gender and Schooling. Hutchinson, London.

- Søndergaard, D-M. (1996): Tegnet på kroppen.

Museum Tusculanum, København.

- Thorne, B. (1993): Gender Play: Girls and Boys in School. Open University Press, Buckingham. . Walkerdine, V. (1989): Counting Girls Out. Virago Press, London.

. Walkerdine, V. (1990): Schoolgirl Fictions. Verso, London.

- Wernersson, I. (1977): Könsdifferentiering $i$ grundskolan. Göteborg Studies in Educational Sciences 22, University of Göteborg.

-Whyte, J. (1983): Beyond the Wendy House: Sex role stereotyping in the Primary School. Longman for School Council, York.

-Willis, P. (1977): Learning to Labor. Guilford.

- Öhrn, E. (1991): Könsmönster $i$ klassrumsinteraktion. Göteborg Studies in Educational Sciences 77, University of Göteborg.

- Ørum, B. (1973): Könsforskelle blandt skoleungdom. Socialforskningsinstituttets publikationer nr. 59, København.

\section{SUMMARY}

Equality versus difference between girls and boys has been a returning issue in Scandinavian educational debates in this century. Until the turn of the century gender differentiation was an explicit goal of education. While this lost favour in the period after the Second World War, when the political ideology of equal rights and the educational ideology of child centred development and learning gained dominance, many of the assumptions and practices constitutive of gender difference remained remarkably intact. The apparently ungendered child in the child centred ideology was actually thought of and described as a generic male - and in classroom studies 'students' were often, in fact, boys. During the 1970s and 80s feminist researchers began to make girls visible in the classroom again and to reveal the problematic patterns hidden by the cloak of egalitarian educatio- 
nal discourses. They found that the gender neutrality of the modern school was an illusion. Sex/gender had remained a major organising principle of the classroom under the claim and intention of gender neutrality. The article presents the main results of this research and discusses its major theoretical explanations from the 1970s, 1980s and 1990s: gender power, gender identity and gender construction. The question is raised whether girls and boys today still fit into the empirical picture and the theoretical framings of the previous decades. Are sex/gender still an issue in school - or are boys and girls becoming ungendered pupils once again?

Harriet Bjerrum Nielsen, cand.mag, professor, faglig leder ved Senter for kvinneforskning, Universitet i Oslo 